Pak. j. sci. ind. res. Ser. B: biol. sci. 2020 63B(3) 187-198

\title{
Accumulation and Translocation of Micro-Nutrients in Soil and Plants of Orchard and Non-Orchard Fields
}

\author{
Nazish Huma Khan*, Mohammad Nafees, Tooba Saeed, Abdullah Khan and Adila Bashir \\ Department of Environmental Sciences, University of Swabi, Pakistan
}

(received January 16, 2019; revised October 16, 2019; accepted October 17, 2019)

\begin{abstract}
The present study was conducted in the Plum orchard zone of district Peshawar. The study was aimed to investigate the levels of different micronutrients in the orchard soil and crop in corresponding to non-orchards. For this purpose, samples of soil and seasonal crop (wheat crop) were collected from both orchard and non-orchard fields. The collected samples were analyzed for various metals such as $\mathrm{Mn}, \mathrm{Fe}$, $\mathrm{Cu}, \mathrm{Zn}, \mathrm{Cd}, \mathrm{Cr}, \mathrm{Ni}$ and Co through Atomic Absorption Spectrophotometer. The results showed that in orchard soils, mean concentrations of $\mathrm{Mn}(486.9 \mathrm{mg} / \mathrm{Kg}), \mathrm{Cu}(81.66 \mathrm{mg} / \mathrm{Kg}), \mathrm{Cd}(2.21 \mathrm{mg} / \mathrm{Kg}), \mathrm{Cr}(54.2$ $\mathrm{mg} / \mathrm{Kg})$ and $\mathrm{Ni}(27.9 \mathrm{mg} / \mathrm{Kg})$ were observed above their allowable limits. Similarly, in orchard wheat crops, a higher accumulation of $\mathrm{Fe}(416.1 \mathrm{mg} / \mathrm{Kg}), \mathrm{Cu}(18.6 \mathrm{mg} / \mathrm{Kg}), \mathrm{Cr}(1.5 \mathrm{mg} / \mathrm{Kg})$ and $\mathrm{Cd}(0.63 \mathrm{mg} / \mathrm{Kg})$ was calculated in the wheat grain/seed part. In non-orchards, all metals were found at safe levels. Analysis of the irrigation water revealed higher limits of $\mathrm{Mn}(0.06 \mathrm{mg} / \mathrm{L}), \mathrm{Fe}(1.94 \mathrm{mg} / \mathrm{L}), \mathrm{Cd}(1.29 \mathrm{mg} / \mathrm{L}), \mathrm{Cr}(3.14$ $\mathrm{mg} / \mathrm{L})$ and $\mathrm{Ni}(1.23 \mathrm{mg} / \mathrm{L})$. Geo-accumulation Index showed a moderate and heavy level of contamination in orchard soils $\left(\mathrm{I}_{\mathrm{geo} .}<1,2\right)$. Higher uptakes of $\mathrm{Mn}(0.81)$ and $\mathrm{Cu}(0.87)$ were calculated in wheat crops of orchards through Transfer Factor (TF). Based on the observations, it is concluded that metals enrichment in orchard fields can be attributed due to excessive applications of fungicide sprays, fertilizers and contaminated water sources that introduce trace-elements into the soil and are subsequently absorbed by plants. Therefore, it is considered important to take appropriate measures to monitor the soils, crops and water for different micronutrients.
\end{abstract}

Keywords: contamination, fungicides, micronutrients, transfer factor, wheat crop

\section{Introduction}

Contamination of soil, water and the food system with trace elements can pose risks to plants, animals and humans (Bolan et al., 2014). Trace elements are also known as micronutrients because they are needed in small amounts for the growth of plants and animals (Shirisha et al., 2014). Micronutrients are more prevalent in surface soils, but plants absorb micronutrients from the lower parts of the soil (Nazir et al., 2015). Micronutrients in the soil can affect crop quality and production. Although their lack or low availability can seriously disrupt plant production and the health of animals and humans (Naser et al., 2012). Metals such as Mn, Fe, $\mathrm{Zn}, \mathrm{Cu}$ and $\mathrm{Ni}$ act as micronutrients at lower concentrations and toxic at higher concentrations (Singh et al., 2010). At higher concentrations, micronutrients congregate for a long time in the soil and have adverse effects on soil and crop quality. Whereas, $\mathrm{Cr}$ and $\mathrm{Cd}$ are considered toxic even at their low level (Behera et al., 2011).

*Author for correspondence;

E-mail: humakhan@uoswabi.edu.pk
Plants need nutrients for their growth, which come from the soil. Therefore, plants are considered to accumulate different nutrients from their surroundings. The accumulation of metals in plants is associated with plant species, growth stages, climatic conditions and particularly soil type (Bangash et al., 2011). Plants grown on a metals rich soil, often show metals uptake by the root system (Ivezic et al., 2013).

Soil contamination with toxic metals arises from anthropogenic sources that are the origin of potential risks (Eded, 2012). Soil amendments, including minerals and organic fertilizers are the major sources involved in introducing micronutrients into soil (Kumar and Chopra, 2013). The intensive use of fungicides/pesticides in horticulture practices is a serious threat to the soil environment (Cheng et al., 2015). Long-term irrigation of agricultural fields with wastewater causes accumulation of metals in soil and plants. It also leads to food safety issues and possible health risks (Khan et al., 2013). In these situations, the soil acts as a sink for accumu-lating micronutrients and provides a source for these metals when their quantity exceeds the soil's holding capacity (Selim, 2013). 
Stone fruits such as Plum and Peach are treated with continuous sprays of copper-based fungicides. Fungicides called Bordeaux mixture $\left(\mathrm{CuSO}_{4}+\mathrm{Ca}(\mathrm{OH})_{2}\right)$, are used to protect fruits from fungal attack and to improve production (Khan and Nafees, 2017; Brunetto et al., 2016). Due to repeated applications of fungicides, an excessive amount of $\mathrm{Cu}$ is introduced into the soil. As a result, $\mathrm{Cu}$ uptake in crops and fruits is due to its potential soil accumulation resulting from the regular spraying of Cu-based fungicides (Bolan et al., 2014). The literature has shown that applications of phosphate fertilizers and tannery industries impart $\mathrm{Cr}, \mathrm{Cd}$ and $\mathrm{Ni}$ accumulation. These metals are highly toxic and carcinogenic when present in excess (Khalid et al., 2017; Sabir et al., 2015). Higher accumulation of these metals in soils disturbs the soil ecosystems (Minnikova et al., 2017).

Contamination of soil with micronutrients influences their retention and transport in the soil-water-plants system (Parveen et al., 2012). Regrettably, soil has been depleted of important minerals in which the food/crop is grown. Soil has been considered as a base and is the only hope for a healthy life. Therefore, life is dependent on soil fertility (Bangash et al., 2011). Metals accumulation in the soil is based on several factors such as $\mathrm{pH}$, soil texture, organic content, moisture content etc. (Leblebici et al., 2018).

The literature has revealed that high accumulation of micronutrients in agricultural soils can pose threats to human health (Ping et al., 2011). High accumulation of micronutrients in soil and water resources draws a lot of attention due to their toxicity to humans through the food chain. To verify the level of different micronutrients, the present study also aims to know the nutrient contents in the soil and their uptake by plants to reduce or improve their serving size.

\section{Materials and Methods}

The current work was conducted in the orchard area of district Peshawar. Plum orchards and their adjacent non-orchard fields were selected as study area, located near the highway. The study area is renowned for its horticulture which includes a variety of orchards such as plums, pears, peaches and straw-berries. Because of the growing trend of horticulture, farmers want to get a good yield and therefore use excessive agrochemicals (fertilizers and fungicides). Beside, the availability of irrigation water is also a big problem and that is why farmers use sewage sources for irrigation purposes. By adopting such methods (agro-chemicals and wastewater), soil toxicity is caused by the accumulation of metals in excess. To handle these problems, it is important to regularly monitor soil, water and crop.

Field survey, sample collection and preparation. During the reconnaissance survey, 30 sampling points were selected for both orchard and non-orchard fields. The composite soil samples were collected from selected sites with $0-25 \mathrm{~cm}$ depth with the help of a spade. 6 points were selected randomly ( 3 for each, orchard and non-orchard) after dividing the selected fields into a grid of $1 \mathrm{~m}^{2}$. Each composite sample consisted of 10 randomly selected points, covering $10 \%$ of each site. Each sample was taken in a labeled clean polythene bag and stored in the laboratory for analysis. The collected soil samples were thoroughly mixed, air passed, crushed to pass through a $2 \mathrm{~mm}$ sieve and stored in labeled plastic pots for laboratory experiments. The irrigation water channels were sampled by collecting five water samples in $2 \mathrm{~L}$ cleaned plastic bottles. Each sample was acidified with $1 \mathrm{~mL}$ of $\mathrm{HNO}_{3}$ to prevent the bacteriological activity and then stored in the laboratory for analysis. The crop and fruit samples were collected randomly at the time of maturity. Both the crop and fruit were oven-dried. Wheat crop was divided into root, shoot, leaf and stem parts and each part was ground, crushed into powder form and stored for analysis.

Chemical analysis. The electrical conductivity and $\mathrm{pH}$ of soil samples were measured with a suspension of $1: 5$, soil/water, using conductivity meter and $\mathrm{pH}$ meter respectively (Richard, 1960). Soil moisture content was determined by oven drying (Polubesova et al., 2009). In this method, an air-dried soil sample of $30 \mathrm{~g}$ was taken in a pre-weighed porcelain dish and weighed. Put the porcelain dish in the oven at $180^{\circ} \mathrm{C}$ for $24 \mathrm{~h}$. After $24 \mathrm{~h}$, the porcelain dish was removed and weighed. Finally, the moisture content of the soil samples was calculated by taking the soil values dried in air and oven in the formula:

Moisture content $=\frac{(\text { Wet weight }- \text { dry weight })}{\text { Dry weight }} \times 100 \%$

Soil texture was measured by the pipette method (Gee and Bauder, 1986). In the pipette method, $20 \mathrm{~g}$ of each soil sample was dissolved in a small amount of distilled water in a shaker cup and $5 \mathrm{~mL}$ of sodium hexametaphosphate was added and stirred for a few minutes. 
The solution was dropped into a $500 \mathrm{~mL}$ cylinder and filled with water, covered with parafilm, inverted and allowed to stand for $48 \mathrm{sec}$. After $48 \mathrm{sec}$, the first aliquot of the top $10 \mathrm{~cm}$ of suspension was taken and labeled it as a $10 \mathrm{~cm}$ pipette. Put the aliquot in a pre-weighted china dish and placed it in oven at $105{ }^{\circ} \mathrm{C}$. After 40 $\mathrm{min}$, another $25 \mathrm{~mL}$ aliquot was taken from the top $5 \mathrm{~cm}$ in a separate pre-weighted china dish and baked at $105^{\circ} \mathrm{C}$. After overnight, the china dish was removed from oven and took its weight for $2^{\text {nd }}$ reading. The differences between initial and final readings were noted. The percentages of sand, silt and clay were calculated using the given formulas:

Clay $(\%)=\frac{20 \times \text { mass of clay }}{\text { Total mass of soil }(20 \mathrm{~g})} \times 100 \%$

Silt $(\%)=\frac{20 \times \text { mass of silt }+ \text { clay-mass of clay }}{\text { Total mass of soil }(20 \mathrm{~g})} \times 100 \%$

$$
\text { Sand }(\%)=100 \%-(\% \text { silt }+\% \text { clay })
$$

Soil organic content was measured by the Walkley black method (Nelson and Sommers, 1982). In this method, $1 \mathrm{~g}$ of soil was taken in a $500 \mathrm{~mL}$ flask followed by the addition of $10 \mathrm{~mL}$ of $\mathrm{K}_{2} \mathrm{Cr}_{2} \mathrm{O}_{7}$ solution and $20 \mathrm{~mL}$. $\mathrm{H}_{2} \mathrm{SO}_{4}$ and stirred this solution for one min. The solution was heated on a hot plate for $5 \mathrm{~min}$ and then allowed to stand for $30 \mathrm{~min}$. After $30 \mathrm{~min}$, the solution was diluted to $200 \mathrm{~mL}$ with distilled water and added 10 $\mathrm{mL} \mathrm{H}_{3} \mathrm{PO}_{4}, 0.2 \mathrm{~g} \mathrm{NaF}$ and 3-4 drops of ferrous indicator and titrated it against $\mathrm{FeNH}_{4} \mathrm{SO}_{4}$ solution. The final reading was noted when the color changed from greenish blue to reddish-brown. The percentage value of carbon content was calculated with the help of given formula:

$\underset{\text { Organic }}{\text { content }(\%)}=\frac{\mathrm{mL} \text { blank-mL sample }\left(\mathrm{MF}_{\mathrm{e}}+2\right)(0.3)}{\text { Wt of dry soil }}$

The metals present in soil, crop and fruit were measured using an aqua-regia $\left(\mathrm{HNO}_{3}: \mathrm{HCl}: \mathrm{HCLO}_{4}, 5: 1: 1\right)$ extraction method. In this method, a soil sample of about $1 \mathrm{~g}$ was digested in $15 \mathrm{~mL}$ of aqua-regia at a temperature of $80-180{ }^{\circ} \mathrm{C}$ to obtain a clear solution. This solution was filtered and diluted with distilled water to $50 \mathrm{~mL}$ and was subjected to a spectrophotometer for analysis. Representative water samples were also subjected to atomic absorption spectrophotometer for micro-nutrients analysis (Chen and Ma, 1998).
Statistical analysis. Mathematical calculations such as mean and standard deviation of analyzed metals were calculated using MS Excel 2007. For the comparative study, t-test was employed in two different domains (orchard and non-orchard) using the SPSS software. Statistically, significant differences were investigated in the average metal concentrations among soil and crop groups. A probability level $p<0.05$ was considered significant. The correlation coefficient was established among soil, water and crop samples using MS Excel, 2007.

Geo-accumulation index. This is used to find the accumulation of metals in soils, represented by $\mathrm{I}_{\text {geo }}$ (Muller, 1969). The accumulation index was calculated using the formula:

$$
\text { Igeo }=\frac{\log _{2} \mathrm{Cn}}{1.5 \times \mathrm{Bn}}
$$

where:

$\mathrm{C}_{\mathrm{n}}=$ is the total metal concentration in soils $(\mathrm{mg} / \mathrm{Kg})$; $B_{n}=$ is the natural background value and 1.5 is the variation in metals quantity due to logarithmic effects.

Muller, (1969) grouped $\mathrm{I}_{\text {geo }}$ into seven classes for each metal.

Class 0 - uncontaminated ( $\left.\mathrm{I}_{\text {geo }} \leq 0\right)$,

Class 1 - uncontaminated to moderately contaminated $(0<$ Igeo $\leq 1)$,

Class 2 - moderately contaminated $\left(1<\mathrm{I}_{\text {geo }} \leq 2\right)$,

Class 3 - moderately to heavily contaminated $\left(2<\mathrm{I}_{\mathrm{geo}} \leq 3\right)$, Class 4 - heavily contaminated $\left(3<\mathrm{I}_{\mathrm{geo}} \leq 4\right)$,

Class 5 - heavily to extremely contaminated $(4<$ Igeo $\leq 5)$, Class 6 - extremely contaminated ( $\left.\mathrm{I}_{\mathrm{geo}} \leq 5\right)$.

Transfer factor. The transfer factor is used to check the transfer efficiency of metals from soil to crop. The plant uptakes from soil was measured as the ratio of metal concentration in crop to the metal concentration in corresponding soil. The TF was calculated for each part of the crop (edible and non-edible) using equation2. Its maximum limit is 1 .

$$
\mathrm{TF}=\frac{\mathrm{C}_{\text {crop }}}{\mathrm{C}_{\text {soil }}}
$$

where:

$\mathrm{C}_{\text {crop }}$ and $\mathrm{C}_{\text {soil }}$, show the metal concentrations in crop and soil samples respectively (Cheng et al., 2015). 


\section{Results and Discussion}

Physico-chemical properties of soil. The analyzed soil samples of orchards showed an average $\mathrm{pH}$ value of 6.07. In their adjacent non-orchard fields, soil $\mathrm{pH}$ ranged as 7.6 (Table 1). Orchard fields were observed with low $\mathrm{pH}$ as compared to agricultural non-orchard fields. $\mathrm{pH}$ of soil is the measure of soil alkalinity or acidity. For soil, the optimal pH range is 7.5-8 (Pietri et al. 2008). The EC was observed in the average range of $630 \mu \mathrm{S} / \mathrm{cm}$ and $610 \mu \mathrm{S} / \mathrm{cm}$ in soils of orchard and non-orchards respectively (Table 1). Soil samples showed low EC values which may be because of low clay contents when compared with national guidelines standards of 2000 $\mu \mathrm{S} / \mathrm{cm}$ (Rayan et al. 2001).

The level of moisture content was 1.7 and $1 \%$ in soils of orchard and non-orchards, respectively. Moisture content is closely linked with soil texture to maintain it at certain level. Sharma et al. (2010) reported that moisture content promotes leaching of nutrients from upper to lower soil layers and thus affects crop production.

Organic matter in soil samples was measured with $2.8 \%$ in orchards and $1.6 \%$ in non-orchards. Results showed high organic contents in orchard fields (Table 1). According to literature, the higher organic contents in orchards can be possible because of the high usage of agrochemicals and tree residues (Gregoricha et al.
2003). The plant residues after decomposition, contributes to soil organic matter and help to improve the soil fertility. Abraham (2013), reported that organic content is responsible for the availability of micronutrients from soil to crop.

The mechanical soil tests showed the enrichment of silt and sand, showing sandy loam and loamy sand nature of soil. These soils possess low water holding capacity when compared to heavy clay textured soils (Table 1).

Soil micronutrients. Among analyzed metals, $\mathrm{Mn}, \mathrm{Cu}$, $\mathrm{Cd}, \mathrm{Cr}$ and $\mathrm{Ni}$ were observed above the permissible limits in orchard soils. In non-orchards, their concentrations were within the allowable limits (Table 2). Literature revealed that in orchard fields, copper availability can be associated to prolong use of $\mathrm{Cu}$ based fungicides to get a good yield (Khan et al., 2017; Fana et al., 2012). Excessive concentrations of $\mathrm{Cu}$ lead to liver cancer and other intestinal diseases in humans (Sun et al., 2010). Therefore, the nutrients found above their permissible limits are regarded as toxic metals.

Literature has shown that $\mathrm{Cr}, \mathrm{Cd}$ and $\mathrm{Ni}$ enrichment in soils is due to anthropogenic activities like excessive uses of agrochemicals (Chen et al., 2015; Khanlari et al., 2008). Iyaka (2011) investigated high dispersion of nickel in the soil structure which caused toxicity to humans via food chain contami-nation. Lu et al. (2014) reported that toxic metals such as $\mathrm{Cd}$ and $\mathrm{Cr}$ accumulate

Table 1. Physico-chemical properties of soil

\begin{tabular}{|c|c|c|c|c|c|c|c|c|c|c|c|c|c|c|c|c|}
\hline \multirow[t]{2}{*}{ Sample } & \multicolumn{3}{|c|}{$\mathrm{pH}$} & \multicolumn{3}{|c|}{$\mathrm{EC} \mathrm{uS} / \mathrm{cm}$} & \multicolumn{3}{|c|}{ Organic carbon $(\%)$} & \multicolumn{3}{|c|}{ Moisture content } & \multirow{2}{*}{$\begin{array}{l}\text { Sand } \\
(\%)\end{array}$} & \multirow{2}{*}{$\begin{array}{l}\text { Silt } \\
(\%)\end{array}$} & \multirow{2}{*}{$\begin{array}{l}\text { Clay } \\
(\%)\end{array}$} & \multirow{2}{*}{ Texture } \\
\hline & Min & Max & Avg & $\overline{\text { Min }}$ & Max & Avg & $\overline{\text { Min }}$ & Max & Avg & Min & Max & Avg & & & & \\
\hline Plum Orchard & 6.03 & 6.11 & 6.07 & 613 & 652 & 630 & 2.4 & 3.8 & 2.8 & 0.7 & 1.9 & 1.7 & 62 & 28 & 10 & Sandy loam \\
\hline Non-Orchard & 7.41 & 7.8 & 7.60 & 588 & 628 & 610 & 1.5 & 1.8 & 1.6 & 0.5 & 1.2 & 1 & 51 & 31 & 16 & Sandy loam \\
\hline
\end{tabular}

Table 2. Concentrations of micro-nutrients in soils of orchard and non-orchards

\begin{tabular}{|c|c|c|c|c|c|c|c|c|c|c|}
\hline \multirow[t]{2}{*}{ Element } & \multicolumn{4}{|c|}{ Orchards } & \multicolumn{4}{|c|}{ Non-Orchards } & \multirow[t]{2}{*}{$\mathrm{P}(2$-tail) } & \multirow{2}{*}{$\begin{array}{l}\mathrm{PL} \text { in soil } \\
\mathrm{mg} / \mathrm{Kg}\end{array}$} \\
\hline & Min & Max & Avg & S.D & Min & $\operatorname{Max}$ & Avg & S.D & & \\
\hline $\mathrm{Fe}(\mathrm{mg} / \mathrm{Kg})$ & 5148 & 5578 & 5302.2 & 16.42 & 3076 & 3920 & 3366 & 13.21 & 0.607 & $21,000 b$ \\
\hline $\mathrm{Mn}(\mathrm{mg} / \mathrm{Kg})$ & 391.4 & 567.03 & 486.9 & 4.06 & 395.1 & 513.04 & 460 & 4.01 & 0.467 & $320 \mathrm{a}$ \\
\hline $\mathrm{Zn}(\mathrm{mg} / \mathrm{Kg})$ & 70.41 & 76.04 & 73.21 & 1.10 & 63.95 & 69.02 & 65.8 & 1.01 & 0.001 & $84.7 \mathrm{a}$ \\
\hline $\mathrm{Cu}(\mathrm{mg} / \mathrm{Kg})$ & 68.91 & 87.52 & 81.66 & 1.31 & 17.52 & 21.13 & 19.03 & 0.03 & 0.000 & $40 \mathrm{~b}$ \\
\hline $\mathrm{Co}(\mathrm{mg} / \mathrm{Kg})$ & 20.44 & 25.01 & 22.13 & 0.04 & 9.44 & 13.16 & 10.05 & 0.01 & 0.019 & -- \\
\hline $\mathrm{Cd}(\mathrm{mg} / \mathrm{Kg})$ & 1.68 & 3.12 & 2.21 & 0.002 & 0.27 & 0.35 & 0.29 & 0.003 & 0.000 & $0.58 \mathrm{a}$ \\
\hline $\mathrm{Cr}(\mathrm{mg} / \mathrm{Kg})$ & 48.3 & 57.03 & 54.2 & 0.88 & 28.54 & 33.18 & 30.42 & 0.08 & 0.001 & $50 \mathrm{c}$ \\
\hline $\mathrm{Ni}(\mathrm{mg} / \mathrm{Kg})$ & 22.8 & 30.15 & 27.9 & 0.06 & 11.36 & 17.01 & 15.04 & 0.02 & 0.002 & $19 a$ \\
\hline
\end{tabular}

Source: (a) Khanlari et al., 2008, (b) Nergus, 2002, (c) Shanker et al., 2005. 
in soil for longer times and pose their toxic effects on the soil and crop grown over there.

$\mathrm{Fe}$ and $\mathrm{Zn}$ were observed within their permissible limits in both orchard and non-orchard fields. Literature revealed that zinc deficiency is associated with excessive applications of phosphate fertilizers (Li et al., 2006). Phosphate fertilizers reduce zinc availability in soil and its availability to plants due to precipitation of $\mathrm{Zn}_{3}$ $\left(\mathrm{PO}_{4}\right)_{2}$. Like other trace-elements, Co was observed high in orchard soils as $22.13 \mathrm{mg} / \mathrm{Kg}$. In non-orchards, the concentrations were observed as $10.05 \mathrm{mg} / \mathrm{Kg}$. In soil, cobalt contamination found rare when compared with other metals (Table 2). Cobalt is non-biodegradable and possesses carcinogenic effects at higher concentrations (Garoui et al., 2011). Results of statistical analysis showed significant differences for $\mathrm{Zn}, \mathrm{Cu}, \mathrm{Co}$, $\mathrm{Cd}, \mathrm{Cr}$ and $\mathrm{Ni}$, while the results were found insignificant for $\mathrm{Fe}$ and $\mathrm{Mn}$.

Micronutrients in wheat crop. In the wheat crop of orchard fields, the grain/seed part showed higher accumulation of $\mathrm{Cu}, \mathrm{Cr}, \mathrm{Fe}$ and $\mathrm{Cd}$ when compared with their permissible limits. In plants, the allowable limit of copper is $10 \mathrm{mg} / \mathrm{Kg}$ (Hassan et al., 2012). For humans, the recommended level of copper is 1.35 $\mathrm{mg}$ /day for adult male and $1.15 \mathrm{mg} /$ day for an adult female by WHO (Sadhra et al., 2007). Cd, Cr, Fe and $\mathrm{Cu}$ contents in wheat grains of orchard fields were significantly higher over non-orchard fields. Furthermore, these metals showed significant results in other parts (stem, leaf, root) of wheat crops showing statistical differences between orchard and non-orchard fields (Table 3).

Pietrzak and McPhail (2004) stated that the prolonged use of $\mathrm{Cu}$ - based fungicides causes toxicity to plants. Teklic et al. (2008) reported that copper richness is harmful to human health. It is carcinogenic in which stores in the liver and brain and therefore, causes Wilson's disease. The research findings showed significantly higher concentrations of $\mathrm{Cd}$ in crop seeds, crossing the permissible limit $(0.02 \mathrm{mg} / \mathrm{Kg})$ recommended by Khan et al. (2008). WHO suggested the daily intake of cadmium in food as $1 \mu \mathrm{g} / \mathrm{Kg}$ per day (Limei et al., 2008).

Similarly, Cr uptakes were observed higher in the wheat plant of orchard fields. In plants, the allowable level for $\mathrm{Cd}$ is $1.30 \mathrm{mg} / \mathrm{Kg}$ (Iqbal et al., 2011). Chromium toxicity badly affects the growth of plants (Rai et al., 2004; Bratakos et al., 2002). Chromium intake for adults has been recommended as 25-35 $\mu \mathrm{g}$ /day by the Food and Nutrition Board and Institute of Medicines (Thor et al., 2011). The findings of the study are supported by Zhang et al. (2011) that accumulation of $\mathrm{Cu}$ and $\mathrm{Cd}$ in soil lead to contamination of agricultural products.

Results for Fe was observed above the permissible limit $(20 \mathrm{mg} / \mathrm{Kg}$ ) recommended by WHO (Shah et al., 2011). In plants, Fe exists with an average rate of $0.005 \%$ (Meng et al., 2005). The recommended nutritional intake of iron is $8-18 \mathrm{mg} /$ day (Tokalioglu et al., 2010). Results of t-tests for iron showed significant differences in all parts of the wheat crop ( $p>0.05)$. In crop grain of orchards, copper, cadmium and chromium were investigated higher because of their higher accumulation in soils. This shows the metals availability to crop where they accumulate in seeds/grains and thus become a part of our food chain. Metals such as $\mathrm{Mn}, \mathrm{Co}, \mathrm{Zn}$ and $\mathrm{Ni}$ were observed below the permissible range (Table 3 ).

In non-orchards, all metals were found safe and below their allowable limits. Fe and $\mathrm{Mn}$ showed greater accumulations in root and stem parts of the wheat crops in both orchard and non-orchards. The USA Institute of Medicine (2002) suggested the level for manganese as $2.3-2.6 \mathrm{mg} /$ day (Carmen et al., 2009). Results of t-test showed insignificant effects in all parts the of wheat plant ( $p>0.05)$.

Cobalt is an essential part of food that improves hemoglobin synthesis. The recommended daily intake for Co is $8 \mu \mathrm{g} / \mathrm{day}$ (Stoica et al., 2004). In crop root of wheat plant, Co was observed in high limit, which can harm the crop. The overall results for cobalt showed the uptakes of cobalt from soil into crop. It's higher concentrations in plant cause leaf drop and reduce shoot weight (Nair et al., 2012). Statistical analysis showed non-significant differences in all parts of the wheat crops ( $p>0.05$ ), given in Table 3.

The results for $\mathrm{Zn}$ found within the allowable limit of WHO as $50 \mathrm{mg} / \mathrm{Kg}$ in plants (Shah et al., 2011). The availability of $\mathrm{Zn}$ has been considered essential for good health. In human diet, the permissible level of $\mathrm{Zn}$ is recommended as $15 \mathrm{mg} /$ day (Tapiero et al., 2003). The t-test showed insignificant effects in analyzed parts of wheat crop for orchard and non-orchards $(\mathrm{p}>0.05)$, Table 3.

Nickel is an important element required for plants and animal's growth. In plants, its permissible limit is recommended as $10 \mathrm{mg} / \mathrm{Kg}$ by WHO (Hassan et al., 2012). The allowable limit of nickel in food is $100-300$ 
Table 3. Concentrations of micro-nutrients in wheat crops

\begin{tabular}{|c|c|c|c|c|c|c|c|c|c|}
\hline \multirow[t]{2}{*}{ Element } & \multicolumn{4}{|c|}{ Orchards } & \multicolumn{4}{|c|}{ Non-orchards } & \multirow[b]{2}{*}{$\mathrm{P}(2$-tail $)$} \\
\hline & Min & $\operatorname{Max}$ & Ave & S.D & Min & Max & Ave & S.D & \\
\hline \multicolumn{10}{|c|}{ Micro-nutrients in seeds of wheat crops } \\
\hline $\mathrm{Fe}(\mathrm{mg} / \mathrm{Kg})$ & 318.7 & 479.5 & 416.1 & 4.07 & 230.4 & 320.6 & 260 & 3.06 & 0.012 \\
\hline $\mathrm{Mn}(\mathrm{mg} / \mathrm{Kg})$ & 289.8 & 462.7 & 392.8 & 4.06 & 267.5 & 435.5 & 381.6 & 4.01 & 0.958 \\
\hline $\mathrm{Zn}(\mathrm{mg} / \mathrm{Kg})$ & 39.41 & 48.8 & 43.5 & 1.04 & 36.5 & 45.01 & 41.33 & 1.02 & 0 \\
\hline $\mathrm{Cu}(\mathrm{mg} / \mathrm{Kg})$ & 15.73 & 21.02 & 18.6 & 0.06 & 5.97 & 8.49 & 7.61 & 0.01 & 0 \\
\hline $\mathrm{Co}(\mathrm{mg} / \mathrm{Kg})$ & 10.32 & 16.34 & 14.10 & 0.04 & 8.76 & 15.52 & 11.31 & 0.03 & 0.426 \\
\hline $\mathrm{Cd}(\mathrm{mg} / \mathrm{Kg})$ & 0.57 & 1.05 & 0.63 & 0.004 & 0.12 & 0.31 & 0.20 & 0.001 & 0 \\
\hline $\mathrm{Cr}(\mathrm{mg} / \mathrm{Kg})$ & 1.38 & 2.03 & 1.5 & 0.016 & 0.89 & 1.07 & 0.92 & 0.012 & 0 \\
\hline $\mathrm{Ni}(\mathrm{mg} / \mathrm{Kg})$ & 5.87 & 8.78 & 7.08 & 0.05 & 4.85 & 6.23 & 5.11 & 0.03 & 0.012 \\
\hline \multicolumn{10}{|c|}{ Micro-Nutrients in stem of wheat crops } \\
\hline $\mathrm{Fe}(\mathrm{mg} / \mathrm{Kg})$ & 278.3 & 426.5 & 376.6 & 3.11 & 188.4 & 283.3 & 241.2 & 2.31 & 0.022 \\
\hline $\mathrm{Mn}(\mathrm{mg} / \mathrm{Kg})$ & 256.4 & 362.8 & 320.6 & 3.04 & 277.5 & 384.6 & 326.5 & 3.06 & 0.889 \\
\hline $\mathrm{Zn}(\mathrm{mg} / \mathrm{Kg})$ & 30.6 & 35.4 & 32.24 & 1.02 & 23.5 & 27.04 & 25.01 & 1.00 & 0.062 \\
\hline $\mathrm{Cu}(\mathrm{mg} / \mathrm{Kg})$ & 6.59 & 8.72 & 7.62 & 0.04 & 2.18 & 4.02 & 3.23 & 0.01 & 0 \\
\hline Co $(\mathrm{mg} / \mathrm{Kg})$ & 8.45 & 14.74 & 11.83 & 0.03 & 9.3 & 13.01 & 10.04 & 0.03 & 0.262 \\
\hline $\mathrm{Cd}(\mathrm{mg} / \mathrm{Kg})$ & 0.16 & 0.25 & 0.18 & 0.002 & 0.06 & 0.15 & 0.09 & 0.001 & 0.004 \\
\hline $\mathrm{Cr}(\mathrm{mg} / \mathrm{Kg})$ & 0.98 & 1.03 & 1.01 & 0.011 & 0.41 & 0.69 & 0.49 & 0.001 & 0.002 \\
\hline $\mathrm{Ni}(\mathrm{mg} / \mathrm{Kg})$ & 1.96 & 3.01 & 2.12 & 0.021 & 0.78 & 1.67 & 1.01 & 0.011 & 0.026 \\
\hline \multicolumn{10}{|c|}{ Micro-nutrients in leaves of wheat crops } \\
\hline $\mathrm{Fe}(\mathrm{mg} / \mathrm{Kg})$ & 421.8 & 634.6 & 581.4 & 5.34 & 200 & 411.3 & 344.2 & 3.04 & 0.013 \\
\hline $\mathrm{Mn}(\mathrm{mg} / \mathrm{Kg})$ & 366.8 & 464.2 & 472.8 & 3.58 & 352.3 & 438.7 & 410.2 & 3.16 & 0.726 \\
\hline $\mathrm{Zn}(\mathrm{mg} / \mathrm{Kg})$ & 32.8 & 37.2 & 34.5 & 1.05 & 21.3 & 24.2 & 22.5 & 1.01 & 0.795 \\
\hline $\mathrm{Cu}(\mathrm{mg} / \mathrm{Kg})$ & 3.9 & 6.7 & 5.7 & 0.011 & 2.8 & 4.3 & 3.1 & 0.011 & 0.055 \\
\hline $\mathrm{Co}(\mathrm{mg} / \mathrm{Kg})$ & 7.3 & 15.07 & 11.4 & 0.07 & 6.35 & 10.01 & 8.4 & 0.04 & 0.061 \\
\hline $\mathrm{Cd}(\mathrm{mg} / \mathrm{Kg})$ & 0.11 & 0.17 & 0.13 & 0.001 & 0.07 & 0.11 & 0.09 & 0.001 & 0.03 \\
\hline $\mathrm{Cr}(\mathrm{mg} / \mathrm{Kg})$ & 0.79 & 0.92 & 0.81 & 0.004 & 0.48 & 0.66 & 0.51 & 0.002 & 0.006 \\
\hline $\mathrm{Ni}(\mathrm{mg} / \mathrm{Kg})$ & 1.1 & 1.78 & 1.33 & 0.003 & 0.47 & 1.03 & 0.52 & 0.001 & 0.002 \\
\hline \multicolumn{10}{|c|}{ Micro-nutrients in roots of wheat crops } \\
\hline $\mathrm{Fe}(\mathrm{mg} / \mathrm{Kg})$ & 646.4 & 880.3 & 678 & 5.06 & 265.8 & 437.5 & 304.7 & 2.41 & 0.002 \\
\hline $\mathrm{Mn}(\mathrm{mg} / \mathrm{Kg})$ & 377.1 & 527.4 & 431.6 & 3.88 & 324.8 & 512.2 & 430.2 & 3.85 & 0.817 \\
\hline $\mathrm{Zn}(\mathrm{mg} / \mathrm{Kg})$ & 34.5 & 44.1 & 40.3 & 1.07 & 35.5 & 41.9 & 38.4 & 1.03 & 0.062 \\
\hline $\mathrm{Cu}(\mathrm{mg} / \mathrm{Kg})$ & 1.42 & 3.01 & 2.2 & 0.005 & 0.87 & 2.6 & 1.8 & 0.003 & 0.043 \\
\hline Co $(\mathrm{mg} / \mathrm{Kg})$ & 19.6 & 26.7 & 23.1 & 0.16 & 7.7 & 10.5 & 8.2 & 0.04 & 0.041 \\
\hline $\mathrm{Cd}(\mathrm{mg} / \mathrm{Kg})$ & 0.03 & 0.08 & 0.06 & 0.000 & 0.01 & 0.06 & 0.03 & 0.000 & 0.007 \\
\hline $\mathrm{Cr}(\mathrm{mg} / \mathrm{Kg})$ & 0.48 & 0.65 & 0.53 & 0.001 & 0.18 & 0.34 & 0.29 & 0.001 & 0.003 \\
\hline $\mathrm{Ni}(\mathrm{mg} / \mathrm{Kg})$ & 0.92 & 1.49 & 1.08 & 0.002 & 0.65 & 1.02 & 0.72 & 0.001 & 0.031 \\
\hline
\end{tabular}

$\mu \mathrm{g} /$ day (Cempel et al., 2006). Ni showed insignificant results in all parts of wheat (Table 3 ). The comparative study showed high availability of micronutrients. The metals availability in orchards can be attributed due to low $\mathrm{pH}$, high level of organic content and excessive use of agrochemicals.

Micronutrients in fruits. Plums are considered valuable and good sources of micronutrients. The average concentrations of metals in plum fruits were observed as $\mathrm{Mn}>\mathrm{Fe}>\mathrm{Ni}>\mathrm{Zn}>\mathrm{Cu}>\mathrm{Cr}>\mathrm{Cd}>\mathrm{Co}$ (Table 4). The contribution of metals in fruits can be associated with fungicide sprays and their uptakes from soil.
Micronutrients in water. The average concentrations of micronutrients in water samples showed high limits of $\mathrm{Mn}, \mathrm{Fe}$ and $\mathrm{Ni}$ when compared with WHO and USEPA standards for the surface water. Toxic metals $(\mathrm{Cd}, \mathrm{Cr})$ were also observed above their permissible limits (Table 5). A canal from the river Kabul is used as a water source for irrigation in the research area. Based on the results, the associated sources involed in water contamination are the release of industries from Hayatabad industrial estate (ICUN, 1994). Khan et al. (2011) investigated micronutrients in surface water of Shah Alam river (a tributary of Kabul river). Water from river Kabul is used as a major source of irrigation 
Table 4. Concentrations of micro-nutrients in plum fruits

\begin{tabular}{lllll}
\hline \hline \multirow{2}{*}{ Element } & \multicolumn{4}{c}{ Micro-nutrients in plum fruits } \\
\cline { 2 - 5 } & Min & Max & Avg & S.D \\
\hline $\mathrm{Fe}(\mathrm{mg} / \mathrm{Kg})$ & 187.3 & 313.8 & 267.6 & 3.01 \\
$\mathrm{Mn}(\mathrm{mg} / \mathrm{Kg})$ & 251.3 & 412.7 & 335.3 & 3.73 \\
$\mathrm{Zn}(\mathrm{mg} / \mathrm{Kg})$ & 0.46 & 1.43 & 0.84 & 0.002 \\
$\mathrm{Cu}(\mathrm{mg} / \mathrm{Kg})$ & 2.83 & 4.04 & 3.80 & 0.011 \\
$\mathrm{Co}(\mathrm{mg} / \mathrm{Kg})$ & 0.27 & 0.32 & 0.29 & 0.001 \\
$\mathrm{Cd}(\mathrm{mg} / \mathrm{Kg})$ & 0.20 & 0.41 & 0.30 & 0.001 \\
$\mathrm{Cr}(\mathrm{mg} / \mathrm{Kg})$ & 0.66 & 0.85 & 0.72 & 0.002 \\
$\mathrm{Ni}(\mathrm{mg} / \mathrm{Kg})$ & 1.43 & 2.01 & 1.73 & 0.002 \\
\hline \hline
\end{tabular}

Table 5. Micronutrients in water

\begin{tabular}{llllllllll}
\hline \hline Samples & $\mathrm{Mn}$ & $\mathrm{Fe}$ & $\mathrm{Zn}$ & $\mathrm{Cu}$ & $\mathrm{Co}$ & $\mathrm{Cd}$ & $\mathrm{Cr}$ & $\mathrm{Ni}$ \\
\cline { 2 - 9 } & \multicolumn{7}{c}{$(\mathrm{mg} / \mathrm{L})$} \\
\hline $\mathrm{S}_{1}$ & 0.08 & 0.6 & 0.02 & 0.13 & 0.02 & 1.02 & 1.12 & 1.05 \\
$\mathrm{~S}_{2}$ & 0.06 & 1.7 & 0.01 & 0.02 & 0.001 & 0.19 & 1.01 & 0.03 \\
$\mathrm{~S}_{3}$ & 0.04 & 0.6 & 0.21 & 0.51 & 0.03 & 0.14 & 0.05 & 0.10 \\
$\mathrm{~S}_{4}$ & 0.06 & 0.9 & 0.01 & 0 & 0.002 & 1.01 & 3.36 & 1.20 \\
$\mathrm{~S}_{5}$ & 0.04 & 1.5 & 0.03 & 0.31 & 0.001 & 2.01 & 1.03 & 0.30 \\
$\mathrm{~S}_{6}$ & 0.08 & 1.7 & 0.22 & 0.02 & 0.03 & 0.90 & 0.34 & 1.05 \\
Average & 0.06 & 1.94 & 0.08 & 0.35 & 0.013 & 1.29 & 3.14 & 1.23 \\
S.D & 0.001 & 0.021 & 0.001 & 0.004 & 0.0001 & 0.072 & 0.141 & 0.031 \\
WHO & 0.05 & 1 & 3 & 2 & 0.04 & 0.01 & 0.05 & 0.2 \\
Stan- & & & & & & & & \\
dards & & & & & & & & & \\
USEPA & 0.05 & 0.3 & 5 & 1.3 & - & 0.005 & 0.1 & 0.1 \\
1986 & & & & & & & & \\
\hline \hline
\end{tabular}

Table 6. Geo-accumulation index of micronutrients in orchard and non-orchard soils

\begin{tabular}{lllllllll}
\hline \hline $\begin{array}{l}\text { Metals } \\
(\mathrm{mg} / \mathrm{Kg})\end{array}$ & $\mathrm{Fe}$ & $\mathrm{Mn}$ & $\mathrm{Zn}$ & $\mathrm{Cu}$ & $\mathrm{Co}$ & $\mathrm{Cd}$ & $\mathrm{Cr}$ & $\mathrm{Ni}$ \\
\hline Orchard & 0.77 & 1.30 & 0.17 & 3.41 & 0.00 & 2.11 & 1.84 & 1.25 \\
Non- & 0.53 & 0.80 & 0.15 & 0.09 & 0.00 & 0.10 & 0.00 & 0.16 \\
Orchard & & & & & & & & \\
\hline \hline
\end{tabular}

therefore the accumulation of metals in agricultural products takes place which contaminates the food chain. Iqbal et al. (2011) analyzed the higher concentration of micro-nutrients in soil and crop samples. This contamination was due to industrial wastewater, used for irrigation. Khan et al. (2013) stated that the use of wastewater for irrigation cause a high accumulation of micronutrients in agricultural soils, crops, vegetables and fruits. Shah et al. (2012) reported that the use of contaminated source of water for agricultural practices is closely associated with health risks. The results of the present study showed that irrigation water is involved in metals introduction into crop grown on contaminated soil.

Geo-accumulation index. High $\mathrm{I}_{\text {geo }}$ values were calculated for orchard soils. $\mathrm{Cu}$ and $\mathrm{Cd}$ were observed with moderate heavy contamination. $\mathrm{Mn}, \mathrm{Ni}$ and $\mathrm{Cr}$ showed class-1 level of contamination while Fe and $\mathrm{Zn}$ ranged in class- 0 (Table 6). This shows the contamination of orchard soils because of the higher accumulation of metals due to prolong use of agrochemicals. On other hand, non-orchards were observed uncontaminated with safe index values.

Transfer factor. Transfer factor for $\mathrm{Mn}$ and $\mathrm{Cu}$ showed maximum values. The overall trend of metals transfer in wheat crops of both orchard and non-orchard fields was as $\mathrm{Cu}>\mathrm{Mn}>\mathrm{Co}>\mathrm{Fe}>\mathrm{Cd}>\mathrm{Zn}>\mathrm{Ni}>\mathrm{Cr}$ (Table 7). Higher uptakes were calculated for crop seeds only. The overall results showed the availability of nutrients in all parts of wheat plants. The differences in transfer factor among different parts of wheat crops may be attributed to variation in metal concentrations in soil and then their uptakes by different parts of wheat crop, while in plum fruit, the TF values were as $\mathrm{Cu}>\mathrm{Mn}>\mathrm{Cd}>$ $\mathrm{Ni}>\mathrm{Zn}>\mathrm{Fe}>\mathrm{Cr}>\mathrm{Co}$ (Table 7).

Table 7. Transfer factor from soil to wheat crop and fruits

\begin{tabular}{llllllllll}
\hline \hline Field & Sample & $\mathrm{Mn}$ & $\mathrm{Fe}$ & $\mathrm{Zn}$ & $\mathrm{Cu}$ & $\mathrm{Co}$ & $\mathrm{Cd}$ & $\mathrm{Cr}$ & $\mathrm{Ni}$ \\
\hline Wheat crop in orchards & Seed & 0.81 & 0.08 & 0.23 & 0.87 & 0.54 & 0.28 & 0.02 & 0.25 \\
& Stem & 0.65 & 0.07 & 0.09 & 0.42 & 0.54 & 0.07 & 0.02 & 0.07 \\
& Leaf & 0.88 & 0.17 & 0.07 & 0.47 & 0.52 & 0.05 & 0.01 & 0.04 \\
& Root & 0.97 & 0.15 & 0.02 & 0.69 & 0.84 & 0.02 & 0.01 & 0.04 \\
Wheat crop in non-orchards & Seed & 0.83 & 0.11 & 0.43 & 0.78 & 0.45 & 0.25 & 0.02 & 0.07 \\
& Stem & 0.34 & 0.10 & 0.17 & 0.71 & 0.91 & 0.08 & 0.01 & 0.05 \\
& Leaf & 0.36 & 0.17 & 0.17 & 0.88 & 0.70 & 0.06 & 0.01 & 0.02 \\
\multirow{3}{*}{ Plum fruit } & Root & 0.54 & 0.11 & 0.10 & 0.92 & 0.88 & 0.04 & 0.01 & 0.03 \\
\hline \hline & & 0.61 & 0.03 & 0.01 & 0.50 & 0.01 & 0.09 & 0.01 & 0.06 \\
\hline
\end{tabular}


Table 8. Correlation $\left(\mathrm{R}^{2}\right)$ of metals

\begin{tabular}{|c|c|c|c|c|c|c|c|c|c|}
\hline \multirow[t]{2}{*}{ Field } & \multicolumn{9}{|c|}{ Metals correlation $\left(R^{2}\right)$ between crop and soils } \\
\hline & Sample & $\mathrm{Mn}$ & $\mathrm{Fe}$ & $\mathrm{Zn}$ & $\mathrm{Cu}$ & $\mathrm{Co}$ & $\mathrm{Cd}$ & $\mathrm{Cr}$ & $\mathrm{Ni}$ \\
\hline \multirow[t]{4}{*}{ Wheat crop in orchards } & Seed & 0.681 & 0.661 & 0.387 & 0.788 & 0.284 & 0.633 & 0.691 & 0.863 \\
\hline & Stem & 0.456 & 0.632 & 0.181 & 0.165 & 0.115 & 0.258 & 0.133 & 0.297 \\
\hline & Leaf & 0.315 & 0.105 & 0.049 & 0.069 & 0.303 & 0.321 & 0.867 & 0.894 \\
\hline & Root & 0.805 & 0.661 & 0.489 & 0.346 & 0.588 & 0.012 & 0.412 & 0.636 \\
\hline \multirow[t]{4}{*}{ Wheat crop in non-orchards } & Seed & 0.452 & 0.557 & 0.590 & 0.751 & 0.139 & 0.139 & 0.185 & 0.106 \\
\hline & Stem & 0.056 & 0.003 & 0.784 & 0.064 & 0.439 & 0.003 & 0.811 & 0.622 \\
\hline & Leaf & 0.078 & 0.067 & 0.445 & 0.352 & 0.158 & 0.039 & 0 & 0.116 \\
\hline & Root & 0.141 & 0.287 & 0.022 & 0.922 & 0.55 & 0.104 & 0.059 & 0.436 \\
\hline \multirow[t]{2}{*}{ Plum Fruit } & 0.405 & 0.071 & 0.012 & 0.078 & 0.197 & 0.021 & 0.039 & 0.132 & \\
\hline & \multicolumn{9}{|c|}{ Metals correlation $\left(R^{2}\right)$ between crop and water Samples } \\
\hline \multirow{4}{*}{ Wheat crop in orchards } & Seed & 0.223 & 0.122 & 0.047 & 0.323 & 0.043 & 0.640 & 0.532 & 0.671 \\
\hline & Stem & 0.050 & 0.154 & 0.002 & 0.12 & 0.267 & 0.086 & 0.013 & 0.084 \\
\hline & Leaf & 0.062 & 0.231 & 0.034 & 0.001 & 0.514 & 0.061 & 0.012 & 0.054 \\
\hline & Root & 0.455 & 0.642 & 0.001 & 0.031 & 0.137 & 0.012 & 0.02 & 0.041 \\
\hline \multirow[t]{4}{*}{ Wheat crop in non-orchards } & Seed & 0.451 & 0.093 & 0.003 & 0.013 & 0.021 & 0.492 & 0.611 & 0.142 \\
\hline & Stem & 0.302 & 0.464 & 0.002 & 0.051 & 0.324 & 0.072 & 0.011 & 0.062 \\
\hline & Leaf & 0.051 & 0.032 & 0.015 & 0.067 & 0.263 & 0.074 & 0.011 & 0.013 \\
\hline & Root & 0.664 & 0.315 & 0.001 & 0.015 & 0.028 & 0.327 & 0.665 & 0.542 \\
\hline Plum fruit & 0.314 & 0.271 & 0.013 & 0.166 & 0.036 & 0.012 & 0.371 & 0.325 & \\
\hline
\end{tabular}

Metals correlations. Among the micronutrients, Mn $\left(\mathrm{R}^{2}=0.681\right), \mathrm{Fe}\left(\mathrm{R}^{2}=0.661\right), \mathrm{Cu}\left(\mathrm{R}^{2}=0.788\right), \mathrm{Cd}$ $\left(\mathrm{R}^{2}=0.633\right), \mathrm{Cr}\left(\mathrm{R}^{2}=0.691\right)$ and $\mathrm{Ni}\left(\mathrm{R}^{2}=0.863\right)$ showed close associations between soil to crop seeds in orchard fields. $\mathrm{Mn}, \mathrm{Fe}$ and $\mathrm{Cu}$ also showed strong correlations in orchard fields. In non-orchards, strong correlations were observed for $\mathrm{Zn}, \mathrm{Cu}, \mathrm{Cr}$ and $\mathrm{Ni}$ in seed and stem parts of the wheat crops (Table 8).

Water samples showed strong correlations with $\mathrm{Fe}, \mathrm{Cd}$ and $\mathrm{Ni}$ in crop root and seed of orchard fields as $\left(\mathrm{R}^{2}=0.642\right),(0.640)$ and $(0.671)$, respectively. In nonorchard adjacent fields, only $\mathrm{Mn}$ and $\mathrm{Cr}$ showed close associations in crop root and seeds respectively. The micronutrients in plum fruits were observed weak in correlations to both soil and water samples(Table 8). Results revealed that both soil and water are responsible for the availability of micronutrients in wheat crops.

\section{Conclusion}

Enrichment of micronutrients was higher in orchard fields. Among the trace elements, zinc has been found below the standards and its deficiency can affect plants growth by lowering soil output. On other hand, unnecessary levels of $\mathrm{Cr}, \mathrm{Cd}, \mathrm{Ni}, \mathrm{Fe}$ and $\mathrm{Cu}$ were measured in the same soils. Another significant finding is the higher accumulation of $\mathrm{Cr}, \mathrm{Cu}, \mathrm{Cd}$, and $\mathrm{Ni}$ in the wheat grains. The Transfer factor for the metals showed their uptake in seeds of orchard crop. Based upon investigations, it has been concluded that anthropogenic activities such as intensive use of fungicides spray and fertilizer application is one of the sources of soil contamination indirectly involved in the contamination of food/crops grown in these areas. Consumption of metal contaminated crops and fruits could be detrimental to the health of people who consistently consume such crops and fruits from their land. To reduce the metal load, it is therefore recommended to develop strategies to prevent long-term soil quality by reducing the metal inputs to agricultural lands.

\section{Acknowledgement}

Nazish Huma Khan is the original author who did work under the supervision of Prof. Dr. Mohammad Nafees and Dr. Abdullah Khan, while Tooba Saeed and Adila Bashir helped in field work and laboratory analysis.

Conflict of Interest. The authors declare no conflict of interest.

\section{References}

Abraham, J. 2013. Organic carbon estimations in soils: Analytical protocols and their implications. Rubber Science, 26: 45-54.(https://www.academia.edu/ 11517799/ORGANIC CARBON) 
Bangash, J.A., Arif, M., Khan, F., Khan, F. 2011. Effect of season and soil concentration on the uptake of minerals in Portulaca oleracea. Journal of Agricultural and Biological Sciences, 6: 52-61 (ISSN 1990-6145: www.arpjournals.com)

Behera, S.K., Singh, M.V., Singh, K.N., Todwal, S. 2011. Distribution variability of total and extractable zinc in cultivated acid soils of India and their relationship with some selected soil properties. Geoderma, 162: 242-250 (https://doi.org/ 10.1016/ j.geoderma.2011.01.016)

Bolan, N., Kunhikrishnan, A., Thangarajan, R., Kumpiene, J., Park, J., Makino, T., Kirkham, M.B., Scheckel, K. 2014. Remediation of heavy metal contaminated soils to mobilize or to immobilize. Journal of Hazardous Materials, 266: 141-166 (https://doi.org/10.1016/j.jhazmat.2013.12.018)

Bratakos, M.S., Lazos, E.S., Bratakos, S.M. 2002. Chromium content of selected Greek foods. Science Total Environment, 290: 47-58 (https://doi.org/ 10.1016/S0048-9697(01)01057-9)

Carmen, C.V., Paula, B. 2009. Chromium and manganese levels in convenience and fast foods. Food Chemistry, 117: 757-763 (https://doi.org/10.1016/ j.foodchem.2009.04.060)

Cempel, M., Nikel, G. 2006. Nickel, a review of its sources and environmental toxicology. Polish Journal of Environmental Studies, 15: 375-382 (www.pjoes.com > Nickel-A-Review-of-ItsSources-and-Environmental)

Chen, H.Y., Teng, Y.G., Lu, S.J., Wang, Y.Y., Wang, J.S. 2015. Contamination features and health risk of soil heavy metals in China. Science Total Environment, 512-513: 143-153 (https://doi.org/ 10.1016/j.scitotenv.2015.01.025)

Chen, M., Ma, L.Q. 1998. Comparison of four USEPA digestion methods for metal analysis using certified and Florida soils. Journal of Environmental of Quality, 27: 1294-1300 (http://dx.doi.org/10.2134/ jeq1998. 004724250027000600040)

Cheng, J., Ding, C., Li, X., Zhang, T., Wang, X. 2015. Heavy metals in navel orange orchards of Xinfeng County and their transfer from soils to navel oranges. Ecotoxicology and Environmental Safety, 122: 153-158 (doi: 10.1016/j.ecoenv. 2015.07.022.)

Eded, A. 2012. Genotype specificity of winter wheat (Triticum aestivum) in cadmium, zinc and iron accumulation in grain. Poljoprivreda, 18: $65-75$ (URIhttps://hrcak.srce.hr/83383)

Fana, J., He, Z., Ma, L.Q., Thiago, A.R., Nogueira, Y.,
Wanga, Z., Lianga, P.J. 2012. Calcium water treatment residue reduces copper phytotoxicity in contaminated sandy soils. Journal of Hazardous Materials, 199: 375-382 (doi: 10.1016/j.jhazmat. 2011.11.030)

Food and Nutrition Board and Institute of Medicine. 2001. Chromium in dietary reference intakes for vitamin A, vitamin K, Arsenic, Boron, Chromium, Copper, Iodine, Iron, Manganese, Molybdenum, Nickel, Silicon, Vanadium and Zinc. Available from: http://www.nap.edu/openbook.php? record_id $=10026 \&$ page $=197$

Garoui, E.M., Fetoui, H., Ayadi, F.M., Zeghal, N. 2011. Cobalt chloride induces hepatotoxicity in adult rats and their suckling pups. Exp Toxicol Pathol., 63: 9-15 (doi:10.1016/j.etp.2009.09.003.)

Gee, G.W., Bauder, G.W. 1986. Particle size analysis. In: Methods of Soil Analysis: Part 1, Physical and Mineralogical Methods, Klute, A. (Ed.), $2^{\text {nd }}$ ed. Agronomy, vol. 9, pp. 383-409. American Society of Agronomy and Soil Science Society of America, Madison. (ISBN-13: 978-0-89118-811-7 ISBN-1O: 0-89118-811-8: (https://dl.sciencesocieties.org > pdfs $>$ methodsofsoilan1)

Gregoricha, E.G., Beareb, M.H., Stoklasa, U., Georges, P.S. 2003. Biodegradability of soluble organic matter in maize-cropped soils. Geoderma, 113: 237-252 (https://doi.org/10.1016/S0016-7061 (02)00363-4)

Hassan, Z., Anwar, Z., Khattak, K.U., Islam, M., Khan, R., Khattak, J.Z.K. 2012. Civic pollution and its effect on water quality of river Toi at district Kohat, NWFP. Research Journal of Environmental and Earth Science, 4: 334-339 (agris.fao.org > agrissearch $>$ search).

Iqbal, M.A., Chaudhary, M.N., Zaib, S., Imran, M., Ali, K., Iqbal, A. 2011. Accumulation of heavy metals $(\mathrm{Ni}, \mathrm{Cu}, \mathrm{Cd}, \mathrm{Cr}, \mathrm{Pb})$ in agricultural soils and spring seasonal plants, irrigated by industrial waste water. Journal of Environmental and Technology Management, 2: 1-8 (https://www.researchgate.net publication)

IUCN (The World Conservation Union). 1994. Report by Pakistan Planning, Environment \& Development. Department Civil Secretariat, Peshawar. Department of Environmental Planning and Management Peshawar University Peshawar. pp. 14-28 (https:// portals.iucn.org > library node)

Ivezic, V., Loncaric, Z., Engler, M., Kerovec, D., Singh, B.R. 2013. Comparison of different extraction 
methods representing available and total concentrations of $\mathrm{Cd}, \mathrm{Cu}, \mathrm{Fe}, \mathrm{Mn}$ and $\mathrm{Zn}$ in soil. Poljo Privreda, 19: 53-58 (URI https://hrcak.srce.hr/ 104281)

Iyaka, Y.A. 2011. Nickel in soils: a review of its distribution and impacts. Science Research Essays, 6: 6774-6777 (DOI:10.5897/SREX11.0350)

Khan, N.H., Nafees, M. 2017. Comparative study of copper accumulation and distribution in soil of selected orchard and non-orchard fields. Agriultural Research and Technology, 7: 1-9 (DOI: 10.19080/ ARTOAJ.2017.07.555713)

Khan, S., Shahnaz, M., Jehan, N., Rehman, S., Shah, M.T., Din, I. 2013. Drinking water quality and human health risk in Charsadda district, Pakistan. Journal of Cleaner Production, 30: 1-9 (https://doi. org/10.1016/j.jclepro.2012.02.016)

Khan, T., Muhammad, S., Khan, B., Khan, H. 2011. Investigating the levels of selected heavy metals in surface water of Shah Alam river (a tributary of river Kabul, Khyber Pakhtunkhwa). Journal of Himalayan Earth Sciences, 44: 71-79 (nceg.uop. edu.pk > Vol-44(2)-2011 > Vol-44(2))

Khanlari, Z.V., Jalali, M. 2008. Concentrations and chemical speciation of five heavy metals $(\mathrm{Zn}, \mathrm{Cd}$, $\mathrm{Ni}, \mathrm{Cu}$, and $\mathrm{Pb}$ ) in selected agricultural calcareous soils of Hamadan Province, Western Iran. Arch. Agronomy Soil Sciences, 54: 19-32 (https://doi.org/ 10.1080/03650340701697317)

Kumar, V., Chopra, A.K. 2013. Enrichment and translocation of heavy metals in soil and plant of Vicia faba L. (Faba bean) after fertigation with distillery effluent. International Journal of Agricultural Policy and Research, 1: 131-141 (https://www.semanticscholar.org paper>Enrichm ent-and-translocation)

Leblebici, Z., Kar, M. 2018. Heavy metals accumulation in vegetables irrigated with different water sources and their human daily intake in Nevsehir. Journal of Agricultural Science and Technology, 20: 401415 (URL: http://journals.modares.ac.ir/article-2310914-en.html)

Li, J.T., Qiu, J.W., Wang, X.W., Zhong, Y., Lan, C.Y., Shu, W.S. 2006. Cadmium contamination in orchard soils and fruit trees and its potential health risk in Guangzhou, China. Environmental Pollution, 143: 159-165 (DOI:10.1016/j.envpol.2005.10.016)

Limei, Z., Xiaoyong, L., Tongbin, C., Xiulan, Y., Hua, X., Bin, W., Lixia, W. 2008. Regional assessment of cadmium pollution in agricultural lands and the potential health risk related to intensive mining activities: a case study in Chenzhou city, China. Journal of Environmental Sciences, 20: 696-703 (DOI:10.1016/s1001-0742(08)62115-4)

Lu, X.W., Zhang, X.L., Li, L.Y., Chen, H. 2014. Assessment of metals pollution and health risk in dust from nursery schools in Xian, China. Environmental Research, 128: 27-34. (https://doi. org/10.1016/j.envres.2013.11.007)

Meng, F., Wei, Y., Yang, X. 2005. Iron content and bioavailability in rice. Journal of Trace Elements in Medicine and Biology, 18: 333-338 (https://doi. org/10.1016/j.jtemb.2005.02.008)

Minnikova, T.V., Denisova, T.V., Mandzhieva, S.S., Kolesnikov, S.I., Minkina, T.M., Chaplygin, V.A., Burachevskaya, M.V., Sushkova, S.N., Bauer, T.V. 2017. Assessing the effect of heavy metals from the Novocherkassk power station emissions on the biological activity of soils in the adjacent areas. Journal of Geochemistry Explor, 174: 70-78. (https: //doi.org/10.1016/j.gexplo.2016.06.007)

Muller, G. 1969. Index of geo-accumulation in sediments of the Rhine river. Geo Journal, 2: 108-118. (https: //www.scirp.org > reference >Papers)

Nair, S., Saha, A.J., Singh, S., Ramachandran, V., Singh, S., Thorat, V., Kaushik, C.P., Eapen, S., Souza, S.F.D. 2012. Evaluation of transgenic tobacco plants expressing a bacterial Co-Ni transporter for acquisition of cobalt. Journal of Biotechnology, 161: 422- 428 (DOI:10.1016/j.jbiotec.2012.07.191)

Naser, H.M., Mahmud, N.U., Sultana, S., Gomes, R., Rahman, M. 2012. Trace elements content in vegetables grown in industrially polluted and nonpolluted areas. Bangladesh Journal of Agricultural Research, 37: 515-527 (DOI: 10.3329/bjar.v37i3. 12128)

Nazir, R., Khan, M., Masab, M., Rehman, H., Rauf, N., Shahab, S., Ameer, N., Sajed, M., Mohib Ullah, M., Rafeeq, M., Shaheen, Z. 2015. Accumulation of heavy metals ( $\mathrm{Ni}, \mathrm{Cu}, \mathrm{Cd}, \mathrm{Cr}, \mathrm{Pb}, \mathrm{Zn}, \mathrm{Fe})$ in the soil, water and plants and analysis of physicochemical parameters of soil and water collected from Tanda Dam Kohat. Journal of Pharmaceutical Sciences and Research, 7: 89-97 (https://www. semanticscholar.org > paper > Accumulation-ofHeavy-Metals)

Nelson, D.W., Sommers, L.E. 1982. Total carbon, organic carbon and organic matter. In: Methods of Soil Analysis (Ed. A.L. Page). Part 2. Agronomy Monographs 9.ASA and SSSA, Madison. WI. 
pp. 539-579 (https://www.scirp.org > reference > ReferencesPaper)

Nergus, Y. 2002. Problems of health and environmental geochemistry, Ph.D. Thesis submitted to the Hamdard University Karachi, Pakistan. pp. 90 (shodhganga.inflibnet.ac.in , bitstream , 11_references)

Perveen, S., Samad, A., Nazif, W., Shah, S. 2012. Impact of sewage water on vegetables quality with respect to heavy metals in Peshawar Pakistan. Pakistan Journal of Botany, 44: 1923-1931 (https://www. semanticscholar.org > paper > )

Pietri, J.C.A., Brookes, P.C. 2008. Nitrogen mineralization along a $\mathrm{pH}$ gradient of a silty loam UK soil. Soil Biology and Biochemistry, 40: 797-802 (https://doi.org/10.1016/j.soilbio.2007.10.014)

Pietrzak, U., McPhail. 2004. Copper accumulation, distribution and fractionation in vineyard soils of Victoria, Australia. Geoderma, 122: 151-166 (https://doi.org/10.1016/j.geoderma.2004.01.005)

Ping, L., Hai-Jun, Z., Li-Li, W., Zhao-Hui, L., Jian-Lin, W., Yan-Qin, W., Li-Hua, J., Liang, D., Yu-Feng, Z. 2011. Analysis of heavy metal sources for vegetable soils from Shandong Province, China. Agricultural Sciences in China, 10: 109-119 (https://doi.org/10.1016/S1671-2927(11)60313-1)

Polubesova, T., Borisover, M. 2009. Two components of chloride anion exclusion volume in montmorillonitic soils. Physicochemical Engineering Aspects, 347: 175-179 (https://doi.org/10.1016/ j.colsurfa. 2009.04.002)

Rai, V., Vajpayee, P., Singh, S.N., Mehrotra, S. 2004. Effect of chromium accumulation on photosynthetic pigments, oxidative stress defense system, nitrate reduction, proline level and eugenol content of Ocimum tenuiflorum. Plant Science, 167: 11591169 (https://doi.org/10.1016/j.plantsci. 2004.06.016)

Richard, L.A. 1960. Diagnosis and Improvement of Saline and Alkali Soils, U.S.D.A. Hand Book.

Ryan, J., Estefan, G., Rashid, A. 2001. Soil and plant analysis laboratory manual. ( $2^{\text {nd }}$ eds.), Int Center for Agric Res in the Dry Areas (ICARDA), Aleppo, Syria, pp. 172 (https://www.scirp.org > reference > ReferencesPapers)

Sabir, M., Waraich, E.A., Hakeem, K.R., Ozturk, M., Ahmad, H.R., Shahid, M. 2015. Phytoremediation, Soil Remediation and Plants. Prospects and Challenges Contaminated Soil is Indispensable. Elsevier, Boston. pp. 85-105. Elsevier Inc. (http://dx.doi. org/10. 1016/B978-0-12-799937-1.00004-8)

Sadhra, S.S., Wheatley, A.D., Cross, H.J. 2007. Dietary exposure to copper in the European Union and its assessment for EU regulatory risk assessment. Science Total Environment, 374: 223-234 (https:// doi.org/10.1016/j.scitotenv.2006.12.041)

Khalid, S., Shahid, M., Niazi, N.K., Murtaza, B., Bibi, I., Dumat, C. 2017. A comparison of technologies for remediation of heavy metal contaminated soils. Journal of Geochemical Exploration, 182: 247-268 (https://doi.org/10.1016/j.gexplo. 2016.11.021)

Selim, M. 2013. Transport and retention of heavy metal in soils. Advances in Agronomy, 119: 275-308 (DOI: 10.1016/B978-0-12-407247-3.00005-6)

Shah, A., Niaz, A., Nazeef Ullah, Rehman, A., Akhlaq, M., Zakir, M., Khan, M.S. 2011. Comparative study of heavy metals in soil and selected medicinal plants. Journal of Chemistry, 1-5 (http://dx.doi.org/ $10.1155 / 2013 / 621265)$

Shah, M.T., Ara, J., Muhammad, S., Khan, S., Tariq, S. 2012. Health risk assessment via surface water and sub-surface water consumption in the mafic and ultramafic terrain, Mohmand Agency, Northern Pakistan. Journal of Geochemical Exploration, 118: 60-67 (https://doi.org/10.1016/j.gexplo. 2012.04.008)

Shanker, A.K., Cervantes, C., Loza-Tavera, H., Avudainayagam, S. 2005. Chromium toxicity in plants. Environment International, 31: 739-753 (https://doi.org/10.1016/j.envint.2005.02.003)

Sharma, R.K., Gupta, A.K. 2010. Continuous wave acoustic method for determination of moisture content in agricultural soil. Computers and Electronics in Agriculture, 73: 105-111 (https://doi. org/10.1016/j.compag.2010.06.002)

Shirisha, K., Kanwar, Sahrawat, Devi, P., Wani, S.P. 2014. Simple and accurate method for routine analysis of heavy metals in soil, plant, and fertilizer. Communications in Soil Sciences and Plant Analysis, 45: 2201-2206 (https://doi.org/10.1080/ 00103624.2014. 911303)

Singh, A., Kumar, R., Sharma, Agrawal, M., Marshall, M. 2010. Risk assessment of heavy metal toxicity through contaminated vegetables from waste water irrigated area of Varanasi, India. Tropical Ecology. 51: 375-387 (URL: http://www.tropecol.com/ pdf/ open/PDF_51_2S/J-09.pd.)

Stoica, A.I., Peltea, M., Baiulescu, G.E., Ionica, M. 2004. Determination of cobalt in pharmaceutical 
products. Journal of Pharmaceutical and Biomedical Analysis, 36: 653-656 (DOI: 10.1016/ j.jpba.2004.07.030)

Sun, B.Y., Kan, S.H., Liu, C.S., Zhang, Y.Z., Wu, J. 2010. Effects of agronomic measures on long-term toxicity of low-dose copper for apple trees and classification of amelioration. Journal of AgroEnvironmental Sciences, 29: 251-257 (http://en. cnki.com.cn/Article_en/CJFDTOTALNHBH201002012.htm)

Tapiero, H., Tew, K.D. 2003. Trace elements in human physiology and pathology: zinc and metallothioneins. Biomedicine and Pharmacotherapy, 57: 399411 (https://doi.org/10.1016/S0753-3322(03)000817)

Teklic, T., Hancock, J.T., Engler, M., Paraoikovic, N., Cesar, V. 2008. Antioxidative responses in radish (raphanussativus), plants stressed by copper and lead in nutrient solution and soil. Acta Biologica Cracoviensia Series Botanica, 50: 79-86. (PL ISSN 0001-529: https://www.researchgate.net , publication > 267031705_Antioxidative_resp)

Thor, M.Y., Harnack, L., King, D., Jasthi, B., Pettit, J. 2011. Evaluation of the comprehensiveness and reliability of the chromium composition of foods in the literature. Journal of Food Composition and Analysis, 24: 1147-1152 (https://doi.org/10.1016/ j.jfca.2011.04.006)
Tokalioglu, S., Gurbuz, F. 2010. Selective determination of copper and iron in various food samples by the solid phase extraction. Food Chemistry, 123: 183187 (https://doi.org/10.1016/j.foodchem. 2010. 04.012).

USEPA (United States Environmental Protection Agency). 2000. Risk-based concentration table. Philadelphia PA: United States Environmental Protection Agency, Washington Agency, Washington (http://www.epa.gov/spc/pdfs/ rchandbk.pdf)

WHO (World Health Organization) 2008. Guidelines for drinking water quality, $3^{\text {rd }}$ eds. Recommendations, vol. 1, WHO Press, World Health Organization, 20 Avenue Appia, 1211 Geneva 27, Switzerland (https://www.who.int > water sanitation_health)

Xue, Z.J., Liu, S.Q., Liu, Y.L., Yan, Y.L. 2012. Health risk assessment of heavy metals for edible parts of vegetables grown in sewage-irrigated soils in suburbs of Baoding City, China. Environmental Monitoring and Assessment, 184: 3503-3513 (DOI:10.1007/ s10661-011-2204-6)

Zhang, H.Z., Li, H., Wang, Z., Zhou, L.D. 2011. Accumulation characteristics of copper and cadmium in greenhouse vegetable soils in Tongzhou District of Beijing. Procedia Environmental Sciences, 10: 289-294. (https://doi.org/10.1016/ j.proenv. 2011.09.047) 